\title{
OBJETOS RELACIONAIS AMERÍNDIOS: SOBRE A (IN)VISIBILIDADE DA ARTE KADIWÉU NA NOVELA ALMA GEMEA DA REDE GLOBO
}

LISIANE KOLLER LECZNIESKI ${ }^{1}$

UFSC

RESUMO: Este texto é uma reflexão sobre o papel da cerâmica na vida social dos índios Kadiwéu que vivem na aldeia Bodoquena, situada no Pantanal sul-matogrossense, Brasil. A partir de exemplos etnográficos analiso as relações entre o mundo das artes e o mundo social, argumentando que a cerâmica atua como um eixo central em torno do qual os Kadiwéu tem articulado e dinamizado suas relações com o mundo externo, especialmente o "mundo dos brancos". Esta compreensão marcadamente relacional dos objetos também aponta, de forma reflexiva, para aspectos cruciais da dinâmica ocidental em torno dos objetos, lançando um olhar crítico sobre as nossas concepções de relação humana.

PALAVRAS-CHAVE: arte ameríndia; cerâmica; indios kadiwéu; objetos relacionais.

ABSTRACT: This work examines the role of ceramics in Kadiwéu social life. The Kadiwéu are Amerindians who live in the southern part of Pantanal Matogrossense, Brazil. The relations between art and social world will be described and analyzed through ethnographic examples, showing how the Kadiwéu understand their ceramic as a special way of relating to the external world, markedly the "world of the "whites". This relational understanding of objects also points out, in a reflexive and critical manner, to crucial aspects of western conceptions of human relations.

KEYWORDS: amerindian art; ceramic; kadiwéu indians; relational objects.

\section{Introdução}

O objetivo deste texto é refletir sobre o lugar da arte e dos

\footnotetext{
1Doutora em Antropologia Social pela UFSC estudando infância, gênero e política entre os índios Kadiwéu (Mato Grosso do Sul, Brasil) e Mestre em Antropologia Social pela UFRGS estudando cotidiano, infância e gênero entre crianças de grupos populares numa praça no centro de Porto Alegre (Rio Grande do Sul, Brasil). Dedica-se à pesquisa e divulgação do conhecimento antropológico junto ao grande público. Pesquisadora do Núcleo de Estudos sobre Saúde e Saberes Indígenas (NESSI/UFSC). Participa do Grupo de Estudos sobre Crianças Indígenas, no NEPI (Núcleo de Estudos e Pesquisa Indígena - UFSC). E-mail: 1klecznieski@gmail.com .
}

Espaço Ameríndio, Porto Alegre, v. 4, n. 1, p. 61-91, jan./jun. 2010. 
LISIANE KOLLER LECZNIESKI - Objetos relacionais ameríndios...

objetos no mundo ameríndio a partir da análise da produção e circulação da cerâmica kadiwéu. O fio condutor das análises será a negociação travada entre os Kadiwéu e a Rede Globo de Televisão em torno da produção da novela Alma Gêmea, veiculada pela emissora entre junho de 2005 e março de 2006. Os dados aqui apresentados são de caráter etnográfico e foram obtidos, de forma intermitente, entre 2000 e 2004, quando realizei trabalho de campo junto aos Kadiwéu da aldeia Bodoquena, localizada na Reserva Indígena Kadiwéu, no Pantanal sulmatogrossense ${ }^{2}$. Nesta aldeia vivem aproximadamente 700 das 1629 pessoas que habitam a Reserva Indígena Kadiwéu³.

Os Kadiwéu descendem dos grupos mbayá-guaicuru que, no passado, povoaram ambas as margens do rio Paraguai e a região do Chaco (SÁNCHEZ-LABRADOR, 1910; CASTELNAU, 1850; RODRIGUES DO PRADO, 1839; SUSNIK, 1983 e 1989). Também conhecidos como "índios cavaleiros" - devido a captura e domesticação de cavalos trazidos pelos europeus no início da colonização - falam o kadiwéu, uma língua da família linguística guaicuru, da qual são os únicos representantes, hoje, no Brasil. Sua organização social caracteriza-se pela estratificação de grupos sociais, onde distinguem especialmente famílias "nobres" e famílias de "criados" ou "cativos". Esta diferença entre "castas" ou "estratos sociais" contrasta, de forma notável, com a relativa igualdade que permeia as relações de gênero em geral. As mulheres kadiwéu ocupam um lugar de destaque na sociedade kadiwéu e o prestígio social e político que desfrutam reside, sobretudo, no fato de serem as produtoras e reprodutoras de saberes tradicionais, entre eles a elaborada arte gráfica que recobre os objetos e os corpos das pessoas.

\footnotetext{
2 A etnografia resultou na tese de doutoramento em Antropologia Social intitulada "Estranhos Laços: predação e cuidado entre os Kadiwéu", apresentada em 2005 ao Programa de Pós-Graduação em Antropologia Social, da Universidade Federal de Santa Catarina, Florianópolis, Brasil. Agradeço a Coordenação de Aperfeiçoamento e Pesquisa (CAPES) pela bolsa de doutorado e ao Núcleo Transformações Indígenas (NuTi/PRONEX, Museu Nacional/UFRJ/UFSC) pelo financiamento da viagem à aldeia kadiwéu, em 2006, quando aprofundei as observações relacionadas à arte gráfica, a cerâmica e as pinturas corporais kadiwéu.

${ }^{3}$ Dados da FUNASA (Fundação Nacional de Saúde) disponíveis no site do ISA (Instituto Sócio Ambiental). Cf. http://pib.socioambiental.org/pt/povo/kadiweu .
} 
LISIANE KOLLER LECZNIESKI - Objetos relacionais ameríndios...

Imagem 1: Mulheres kadiwéu entregando cerâmicas à pesquisadora - Aldeia Bodoquena.

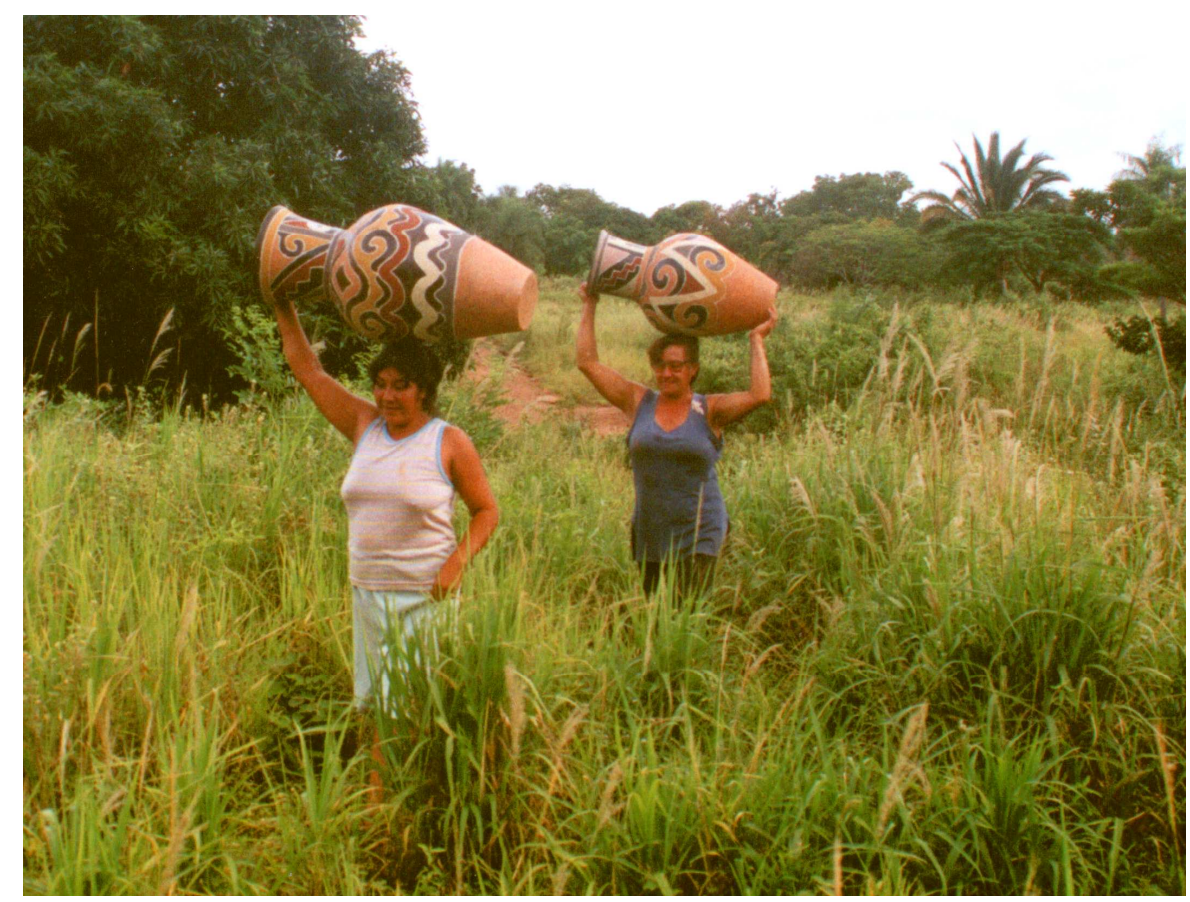

Foto: Lisiane Koller Lecznieski, 2000.

\section{A arte de relacionar-se através da arte}

A arte gráfica Kadiwéu tem sido referida, em diversos relatos, desde o início da colonização européia da região até nossos dias ${ }^{4}$. Estas referências em geral remarcam a beleza e a originalidade dos grafismos, mas também a estranheza, sobretudo das pinturas faciais, frequentemente descritas em termos do forte impacto que causavam nos expectadores externos. O missionário Sánchez-Labrador (apud LÉVI-STRAUSS, 2001, p. 177), por exemplo, indagava o por quê por tamanha fixação pela alteração da aparência do rosto humano, opondo "às graças da Natureza uma feiúra artificiosa"; por quê esse "desprezo pela obra do Criador", "pela argila de que somos feitos?". Lévi-Strauss (1942), por seu lado, primeiramente descreveu as pinturas corporais das

4 Sánchez-Labrador (1910), Félix de Azara (1969), Rodrigues do Prado (1839), Almeida Serra (1845), Boggiani (1975), Colini (1975a e 1975b), Baldus (1975), Lévi-Strauss (2001 e 1996), Ribeiro (1980), Pechincha (1994), Koller Lecznieski (2005), Graziato (2008), entre outros. 
LISIANE KOLLER LECZNIESKI - Objetos relacionais ameríndios...

mulheres kadiwéu como uma "renda negra", cuja beleza e intricácias explicariam o "efeito erótico" que exerce nos homens, sobretudo os forasteiros 5 .

Os registros visuais mais antigos desta arte, no entanto, foram efetuados pelo pintor e comerciante de peles italiano, Guido Boggiani, que viveu entre os Kadiwéu em duas ocasiões. A primeira em 1892, quando reproduziu diversos desenhos e padrões em aquarela e nanquim, a segunda em 1897, quando retornou para registrá-los em placas fotográficas ${ }^{6}$. No diário que manteve durante estas viagens Boggiani descreve, com riqueza de detalhes, não apenas as artes gráficas como também aspectos da vida social kadiwéu. Cenas cotidianas, festas e brincadeiras, com destaque especial para as regras de etiqueta e arte de bem receber que, como nota, eram uma especialidade de seus anfitriões. O autor também menciona trocas efetuadas nas aldeias kadiwéu, sobretudo com as artistas que produziam diversos objetos cobiçados pelos estrangeiros, como pentes esculpidos em osso e madeira, couros pintados, esculturas de madeira, objetos de palha e peças de cerâmica, hoje distribuídas em diferentes museus europeus. Boggiani observa a destreza com que as "Donas" (senhoras kadiwéu) elaboram os desenhos e pinturas e, comentando a perspicácia das artistas no comércio e valorização dos seus produtos, diz-se admirado com a abertura e investimento demonstrados nas relações com alguém que era, no final das contas, um "estranho".

Quase um século mais tarde Lévi-Strauss observa características bastante similares em Tristes Trópicos, livro que tornou a arte gráfica kadiwéu mais amplamente conhecida. Neste livro o autor analisa os padrões gráficos recorrentes nos desenhos corporais e faciais kadiwéu, traçando uma interessante analogia entre o "plano sociológico" inscrito no sistema guaná e bororo e o "plano estilístico" da arte kadiwéu7 (LÉVISTRAUSS, 2001).

Não caberia aqui apresentar as idéias instigantes deste grande

5 O tema, como veremos adiante, foi posteriormente aprofundado por Lévi-Strauss (1996 e 2001). 6 O material encontra-se reunido no texto "Viajes de un artista por la América meridional. Los Caduveos. Expedición al río Nabileque, en la región de las grandes cacerías de venados, Matto Grosso (Brasil)", de 1929 e posteriormente publicado como Os Caduveos, em 1945 - (Cf. BOGGIANI, 1975).

7 Análise que é aprofundada, de uma perspectiva comparativa mais ampla, em "O Desdobramento da Representação nas Artes da Ásia e da América” (LÉVI-STRAUSS, 1996). 
pensador. Quero destacar, no entanto, que suas idéias guiaram meu olhar em campo e inspiraram, de diversas formas, as reflexões aqui tecidas. Meu olhar sobre a arte kadiwéu incidirá, todavia, menos nos grafismos do que nos objetos nos quais os desenhos são aplicados; no caso, as cerâmicas. Para os Kadiwéu, a beleza e originalidade de sua cerâmica estão diretamente ligadas aos grafismos nela inscritos, uma arte descrita como herança dos "antigos", dos "antepassados", ou dos "avós kadiwéu".

Analisando as práticas e representações nativas em torno da cerâmica buscarei entender as relações entre o mundo das artes e o mundo social, argumentando que a cerâmica atua como um eixo central em torno do qual os Kadiwéu tem articulado e dinamizado suas relações com o exterior, com alteridades externas, mais especificamente ${ }^{8}$. Destaca-se, neste contexto, seu caráter eminentemente relacional, onde atuam como dínamos que impulsionam a produção e põe, efetivamente, em circulação, estas magníficas criaturas, que são os vasos kadiwéu.

Procurarei compreender as relações engendradas por estes objetos na vida social, descrevendo as dinâmicas que os envolvem e atentando para as maneiras como são descritos e abordados nas falas nativas, revelando formas bem particulares de pensar e agir, por intermédio dos objetos, sem substanciá-los. Uma concepção que também aponta, por outro lado, aspectos cruciais (embora aparentemente óbvios) da dinâmica ocidental em torno dos objetos, lançando um olhar crítico sobre as nossas concepções e formas de relação com os outros.

Duas observações perspicazmente anotadas por Lévi-Strauss, em Tristes Trópicos, servirão como introdução ao tema. A primeira é um diálogo estabelecido entre o autor e uma velha senhora kadiwéu:

A índia quereria me vender o pote? 'Sem dúvida', que quer. 'Infelizmente', não Ihe pertence. À quem, então? Silêncio. A seu marido? Não. A seu irmão? Também não. A seu filho? Tampouco. É da sua neta. A neta possui inevitavelmente todos os objetos que queremos comprar! Olhamo-la, tem três ou quatro anos, de

\footnotetext{
8 Esta mesma disposição pode ser observada no contexto das pinturas corporais que, enquanto praxis social, atuam como articuladoras importantes das relações com alteridades internas à aldeia, entre Kadiwéus e cativos e/ou não-Kadiwéus.
} 
LISIANE KOLLER LECZNIESKI - Objetos relacionais ameríndios...

cócoras perto do fogo, absorta diante do anel que, ainda há pouco, passei no seu dedo. E começam então, com a senhorita, demoradas negociações em que os pais não têm a menor participação. Um anel e quinhentos réis deixam-na indiferente. Um broche e quatrocentos réis a decidem (LÉVI-STRAUSS, 2001, p. 148).

Lévi-Strauss afirma que só conseguiu adquirir o pote depois de uma "longa" e "paciente" conversa, primeiramente com a velha senhora, depois com sua ilustre neta. Uma conversa que, note-se, gira em torno de relações, envolvendo marido, irmãos, filhos... e a neta. Vale supor que qualquer outro evento relacionado ao tema - caso a senhora não tivesse, por exemplo, filhos ou marido - seria provavelmente motivo de digressões e delongas dialógicas. Além disso, a conversa com esta senhora termina, como vimos, com o início de uma outra conversa, quando uma criança, sua neta, é introduzida no diálogo e na rede, agora como sujeito principal da negociação ${ }^{9}$. Também chama a atenção o fato de o valor monetário do objeto ser colocado em segundo plano, sendo praticamente desprezado, nos dois momentos da negociação.

Noutra passagem, descrevendo seus dias na aldeia, Lévi-Strauss anota que

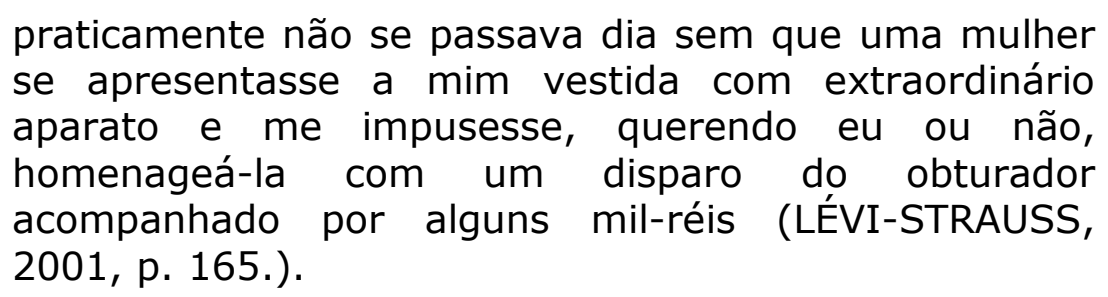

Estas visitas contínuas ao estrangeiro que levava presentes significavam, com certeza, muito mais que um simples meio de obter coisas e/ou alguns mil réis. Embora negociar fosse, obviamente, um ponto comum de interesse, os significados envolvidos, em cada lado, são distintos. Enquanto Lévi-Strauss visava adquirir aquele vaso específico, a índia parecia mais interessada na conversar e seus desdobramentos. 0 desprezo indígena pelo valor monetário dos objetos negociados com o antropólogo deixa isso evidente. A observação de Boggiani (1975) sobre

9 Cabe mencionar aqui que as crianças são vistas pelos Kadiwéu como seres relacionais por excelência, aparecendo como mediadoras importantes na mitologia, nos rituais, nas relações familiares e na própria política kadiwéu. Sobre o tema ver "uma economia política de crianças" em Koller Lecznieski (2005). 
LISIANE KOLLER LECZNIESKI - Objetos relacionais ameríndios...

o interesse demonstrado em relação a sua pessoa, um mero "estranho", é significativa pois recorrente em grande parte da bibliografia sobre o grupo. Os objetos aparecem, sobretudo nos contextos de contato com estrangeiros, como meios/objetos importantes de relação. Mais que negociar objetos, em si, procura-se o forasteiro para conversar, conhecer sua pessoa, apresentar a cultura do grupo, trocar idéias e histórias.

A "homenagem com um disparo do obturador", a que se refere Lévi-Strauss (2001, p. 165), é ainda hoje bastante comum. A diferença é que hoje o pagamento deve ser feito na forma de retribuição de cópias das fotos, ao invés de dinheiro. Muitas vezes famílias inteiras se apresentavam vestidas à rigor para me encontrar e serem fotografadas. Nestas sessões de fotos fui conhecendo pessoas e famílias que me convidavam para visitá-las em suas casas, especialmente "para ver a cerâmica kadiwéu". De fato, a cerâmica era um dos primeiros assuntos que surgiam, nestas visitas, com as ceramistas sempre dispostas a fornecer detalhes sobre a arte de sua produção, quando destacavam a "beleza", "nobreza" e "antiguidade", sobretudo dos desenhos. Estas descrições dos predicados das obras são em geral articuladas como uma forma de evidenciar aos visitantes o valor contido em cada peça e, desta forma, convencê-lo a adquiri-las. Mais que simples motivos de aproximação com os estrangeiros, as cerâmicas (como as fotografias compulsoriamente oferecidas) são "objetos" relacionais também no sentido de que, através deles, os Kadiwéu pretendem mostrar, ao mundo, que existem enquanto grupo étnico diverso, "espalhando" suas imagens "mundo afora", tendo "representação em todas as partes", como dizem, e como veremos mais adiante.

"Como se tivessem vindo voando, com o vento, e pousado lá": sobre a invisibilidade da cerâmica na novela Alma Gêmea

Longe de configurarem momentos perdidos em um passado distante, a dinâmica social envolvida nas cenas descritas por LéviStrauss e Boggiani revela-se em pleno vigor nos dias atuais 
LISIANE KOLLER LECZNIESKI - Objetos relacionais ameríndios...

(PECHINCHA, 1994; LECZNIESKI, 2005; GRAZIATO, 2008; entre outros). A controvérsia gerada entre os Kadiwéu em torno do convite, por parte da Rede Globo de Televisão, para participarem da novela Alma Gêmea, inspirada na cultura do grupo, ilustra bem o ponto de vista que quero aqui enfatizar.

Apesar das disputas internas entre facções políticas rivais - uns recebendo a proposta da Globo com entusiasmo, outros com desconfiança - a maioria das pessoas enfatizou a importância do evento e o impacto que teve na vida da aldeia. Algumas pessoas mencionaram a "retaliação" sofrida por certas famílias, em consequência do episódio ${ }^{10}$. Um aspecto anotado por diversas pessoas, e que quero aqui ressaltar, foi o fato de os Kadiwéu terem se mostrado "abertos à conversa". Como explicou um senhor idoso: "Precisava conhecer o pessoal, saber os motivos de sua curiosidade pelos Kadiwéu, que tipo de gente que eram". Quase nos mesmos termos expressou-se a mãe de uma moça que alimentara expectativas de participar da novela como atriz:

Chegaram já apreciando os desenhos kadiwéu. Mas branco sempre se interessa se vê cerâmica, vê desenho, vê pintura. Parece até que só enxerga índio assim, se faz coisa bonita. Senão, olha, mas nem vê, já esquece (...). Mas fui saber quem eram, de onde vinham, o que queriam aqui na aldeia. Eu tive que saber deles por causa da minha filha, que não sossegava. Tive que ir indagar que tal eram, que tipo de gente, essas coisas (...). Seria muito bom conhecer aquele pessoal [da Globo]! (Conversa com senhora kadiwéu, abril de 2006).

Alguns, mais reticentes, advertiam já ter visto "muita gente ruim, que só quer lucrar em cima do índio". Um rapaz que no início havia estado animado com a idéia da novela, desabafou:

Usam o índio! E depois esquecem que a gente existe (...). Parece que esquecem que as coisas foram feitas por gente de carne e osso, que existe (...). Esse pessoal acho que só se interessa mesmo pelo lado do

10 Uma moça recém casada, por exemplo, reclamou do "retaliamento", dizendo que sua família (de descendência nobre) fora "riscada da lista para receber o material de construção", advindo de um programa social do governo federal. 
LISIANE KOLLER LECZNIESKI - Objetos relacionais ameríndios...

lucro, da fama, essas coisas! (Conversa com jovens kadiwéu na escola da aldeia, abril de 2006).

Afirmando ter sido chamado de "aculturado" pelo fato de exigir pagamento pelo "uso das imagens (cerâmica, desenhos) kadiwéu", um nobre membro da liderança ironizou: "Só eles querem lucrar, se o índio quer o que é de direito, se não abaixa a cabeça, aí já é aculturado; deixa de ser índio na horinha!".

Conversar, conhecer, saber das intenções e curiosidades dos outros, estabelecer relações, ser reconhecidos e respeitados como sujeitos atuantes e com direitos. Concepções relacionais que não são sequer contempladas na negociação empreendida pela Rede Globo, e acabam chocando-se, de forma ainda mais brutal, com a dinâmica comercial que rege a produção dos produtos midiáticos. Como me explicou, por telefone, o "acessor cultural" contratado pela Rede Globo para intermediar as relações com os Kadiwéu, o fato de as negociações "se arrastarem demais" levou a Globo a desistir dos Kadiwéu e contratar outro grupo indígena para substituí-los nas gravações. Um outro motivo de desentendimento, porém, foi mencionado como crucial tanto pelo assessor cultural da Globo, quanto por amigos (brancos, citadinos) dos Kadiwéu, como o caso da dona de uma pequena hospedagem onde os indígenas sempre encontram abrigo quando vão à cidade. A emissora havia "desistido dos Kadiwéu" por causa do pedido de um "pagamento à parte", efetuado por representantes das famílias "nobres". O caráter estratificado da organização social kadiwéu foi interpretado não somente como um fenômeno de aculturação, mas como um fenômeno que deveria ser reprovado e mitigado. Embora se tratasse de uma "quantia irrisória (10 mil reais, em 2000) para uma empresa do porte da Globo", como esclareceu a dona da hospedagem, a reinvidicação foi definida como sinal de "aculturação" e "injustiça", por um lado, e, se era mesmo uma tradição cultural, como explicou a assessoria cultural, era um traço que não deveria ser incentivado, dado que seria "injusto para com os próprios índios", cuja mentalidade é, "por natureza", "coletiva" e "comunitária". Ironicamente, esta recriminação da falta de senso comunitário dos índios kadiwéu parte, justamente, de um grupo empresarial cujos lucros com a novela Alma Gêmea superaram as expectativas da própria emissora, como registrado na página online da 
LISIANE KOLLER LECZNIESKI - Objetos relacionais ameríndios...

emissora ${ }^{11}$.

Me parece importante, nesse contexto, abrir um breve parênteses para informar sobre algumas particularidades relacionadas às noções de hierarquia, bem como os critérios de nobreza, articulados na sociedade kadiwéu. Primeiramente ressalto que, com raras exceções, as famílias de "criados", assim como as de "nobres", possuem e vivem em suas próprias casas. No caso específico da família que me hospedou vivia um senhor com mais de cinquenta anos que, por não ser casado, continuava morando com a família do filho do senhor que o criara, quando pequeno, em companhia de meu anfitrião, que o chamava de "irmão". De fato, é muito comum membros de determinadas famílias "nobres" referirem a membros de determinadas famílias de "criados" como "parentes", e vice-versa. Embora existam assimetrias relacionadas à divisão do trabalho - os criados em geral ajudando na organização das festas de seus "senhores", assim como no cultivo das hortas e nas "carneações", por exemplo - isso não implica na ausência de laços de afetividade e de cooperação mútua, ao contrário. Vários "criados" se dizem satisfeitos com seus senhores e se sentem lisonjeados por poderem contar com sua ajuda, usar seus nomes e compartilhar a cultura kadiwéu. Vale notar, por outro lado, que para ser nobre não basta nascer em uma família nobre. É preciso "mostrar nobreza", sobretudo em suas ações. Enquanto as prerrogativas de nobreza são relacionadas a determinadas famílias e, nesse sentido, remetem a uma ideia de descendência e hereditariedade, estas concepções são relativas $^{12}$ e não estão, necessariamente, relacionadas ao caráter biológico ou genético visto como dado, automaticamente, ao indivíduo. O grau de conhecimento (e prática) das artes (gráficas, cerâmicas, narrativas, guerreiras, etc.) kadiwéu, por exemplo, podem levar uma pessoa não nobre a tornar-se, com o tempo, e com investimento pessoal, em um "legítimo Kadiwéu"13. O seguinte exemplo, registrado

11 Ver http://memoriaglobo.globo.com/Memoriaglobo/0,27723,GYN0-5273-230640,00.html. Conforme notificado neste site "Alma gêmea obteve a maior audiência do horário das $18 \mathrm{~h}$ em toda a história da teledramaturgia da emissora" tendo sido também transmitida pela emissora portuguesa SIC (em 2005) e, através de contrato entre a Pappas telecasting e a TV Globo Internacional, exibida nos Estados Unidos, em 2007. Sucesso internacional, a novela já foi exibida na Costa Rica, Rússia, Peru e Venezuela, entre outros países.

12 Sobre o tema ver Koller Lecznieski (2005).

13 Como o caso do "vereador kadiwéu" que, segundo me explicaram, era Terena criado entre os Kadiwéu e, com tal, falante do idioma, conhecedor das histórias, da mitologia e das tradições do grupo (KOLLER 
LISIANE KOLLER LECZNIESKI - Objetos relacionais ameríndios...

pelo administrador colonial espanhol Félix de Azara, nos idos de 1817, ilustra bem o tom peculiar que permeia as relações entre "nobres" e "cativos". Descrevendo o caso de um senhor Kadiwéu que, acordando numa noite fria para buscar uma manta para cobrir-se e, constatando que seu criado já tivera a ideia antes, sequer cogita tomá-la para si, o autor se mostra perplexo e conclui tratar-se, no mínimo, de uma "esclavitud muy dulce" (AZARA, 1969, p. 217).

Voltando às falas sobre a trama com a Rede Globo, vimos a importância que os índios atribuem à "conversa", ao diálogo e ao "conhecer" nas suas relações com os outros. Mas a dinâmica da conversa, conforme entendida pelos Kadiwéu demanda um tempo e um envolvimento impensável e mesmo incompreensível dentro da lógica empresarial. Apesar da aparência simples e banal destas constatações, veremos que tem fortes implicações nas formas de conceber, sentir e agir no mundo e, nesse sentido, deveriam ser consideradas nos contextos de interação entre grupos sociais regidos por valores e concepções de mundo distintas.

É significativo que esta mesma lógica do capital seja estendida ao "mundo dos brancos", de forma mais ampla, como na seguinte observação feita por uma velha senhora, Dona Matexua:

Hoje está acontecendo com nossos desenhos a mesma coisa que aconteceu com as histórias dos antigos! O branco diz que gosta, que quer [ouvir as histórias], mas não ouve... Ou não aprecia, não sei (...). Já tá lá papel na mão, esperando; tá divulgando, escrevendo livro... Só lucro! Matam! Matam mesmo, acabam com elas [as histórias]! Já não é mais do índio (...). Vão embora e esquecem. Nunca mais! Só pensam em lucrar em cima do índio (Dona Matexua, abril de 2006).

Segundo os Kadiwéu, os "brancos" tem uma "ânsia pelas coisas", para "ser donos das coisas", "dão mais valor ao lucro" do que conhecer pessoas, como exclamou um rapaz:

Você diz que vêm na aldeia porque quer conhecer nós, os Kadiwéu, saber como é a vida, o sistema do índio, que tipo de gente que é. Mas não sei não, branco diz sempre a mesma coisa... Não que eu não acredite na

LECZNIESKI, 2005).

Espaço Ameríndio, Porto Alegre, v. 4, n. 1, p. 61-91, jan./jun. 2010. 
LISIANE KOLLER LECZNIESKI - Objetos relacionais ameríndios...

senhora, mas conheço muitos que já vem com aquilo na cabeça, já com os olhos naquela coisa que eles querem (...). $\mathrm{E}$, depois, fica tudo por isso mesmo! (Conversa com jovens kadiwéu na escola da aldeia, abril de 2006).

É notável a recorrência do termo lucro tanto nas falas dos jovens quanto nas falas dos mais velhos. A mentalidade empresarial e a lógica do capital, antes referidas ao contexto de produção da novela, são significativamente extendidas ao "mundo dos brancos" em geral. Um mundo onde os fins lucrativos sobrepõe-se, na visão nativa, às relações: "Vão embora e esquecem do índio"; "e fica tudo por isso mesmo", ou seja, ninguém conhece ninguém, ninguém estabelece vínculos duradouros com ninguém; ficando "tudo por isso mesmo"14.

O uso da língua kadiwéu por alguns personagens da novela também foi mencionado nas conversas. Um senhor, por exemplo, ria enquanto comentava que as falas pareciam "um arremedo do idioma; homem falando tal qual mulher, mulher tal qual homem!", conforme lhe havia contado uma parente sua, moradora da cidade ${ }^{15}$. Mas isso não pareceu incomodá-los, assim como não se mostraram, para minha surpresa, descontentes com a reprodução de seus grafismos nos corpos dos atores.

O que realmente indignou os Kadiwéu, e com razão, foi a maneira como a sua cerâmica foi apresentada pela emissora na novela. Por um lado, criticaram o fato de a novela ter mostrado "muito pouca cerâmica" e de estas resumirem-se a peças pequenas: "Os brasileiros íam ficar muito mais felizes se mostrassem os vasos grandes e lindos também!", exclamou uma senhora. Acima de tudo, porém, e de forma mais que compreensível, as pessoas reprovaram o fato de sua cerâmica ter sido exibida de forma anônima, sem nenhuma menção ao grupo que the deu origem: "Como se tivesse vindo voando, com o vento, e pousado lá! Como se não fosse criado dos Kadiwéu!", exclamou indignada Marília, uma jovem ceramista. Muitas pessoas diziam não entender o que definiam, em geral, como "um desrespeito": "Desrespeito para com

14 Quando se deparam com pessoas que chegam sozinhas nas aldeias, dispostas a viver entre eles por um tempo determinado, como no caso de pesquisadores, por exemplo, ficam visivelmente impressionados e não param de perguntar sobre os parentes da pessoa e como consegue ficar longe dos seus. 15 Sobre as diferenças entre a fala feminina e masculina ver Sandalo (1996) e Griffits e Griffits (1976).

Espaço Ameríndio, Porto Alegre, v. 4, n. 1, p. 61-91, jan./jun. 2010. 
LISIANE KOLLER LECZNIESKI - Objetos relacionais ameríndios...

nossos avós"; "Desrespeito com quem tanto fez pelo Brasil"; "Um povo que viu a terra ficar vermelha com o sangue vertido dos parentes" (em referências à participação Kadiwéu na guerra contra o Paraguai, em 1864), entre outras críticas. Um membro da liderança chegou a afirmar (mas não pude confirmar) que a ACIRK (Associação das Comunidades Indígenas da Reserva Kadiwéu) havia "movido processo (judicial) contra a Globo", para que reconhecesse "os direitos Kadiwéu" e "a memória dos antigos". Porque "Kadiwéu tem seu sistema, seu modo de pensamento, mas os brancos pensam que índio é tudo igual!". Uma jovem que havia apoiado o projeto disse sentir-se duplamente "traída": por um lado, pelos "patrícios", que "barraram o projeto", por outro, pela Globo, que no final mostrou "um grande desrespeito" pelo seu povo. É importante ressaltar, neste contexto, que enquanto o etnônimo Kadiwéu não foi mencionado nenhuma vez durante a trama, as entrevistas de atores, produtores e diretores da novela mencionam, recorrentemente e em diferentes veículos de comunicação, os Kadiwéu e sua arte gráfica como fonte principal de inspiração da trama16.

Além do desrespeito para com o povo, e para com o próprio objeto, em si - como implícito na fala de Marília - o aspecto mais enfatizado, nas falas, é o de os objetos de cerâmica envolverem e remeterem, necessariamente, a relações: com aqueles que os produziram, aqueles que os adquiriram e àqueles de quem vem a sabedoria para fazê-los, os antepassados kadiwéu.

\section{A cerâmica e seus efeitos espelhares}

Antes de prosseguir gostaria de anotar, sucintamente, alguns aspectos do processo de "levantamento" das cerâmicas pelas artistas. $\mathrm{O}$ barro é coletado na Reserva e a ele são misturadas outras substâncias, como cinzas de diferentes madeira e pó de cerâmicas quebradas ou velhas, que darão "o ponto" e determinarão a qualidade final da cerâmica. Depois de longamente amassar esta mistura (processo também ligado à "qualidade" da peça), as ceramistas "levantam o barro",

16 Ver, por exemplo, http://www.terra.com.br/istoegente/306/diversao arte/tv_eduardo priscila.htm e http://www.gazetanews.com/arte_cultura.php?cd_noticia $=1086$.

Espaço Ameríndio, Porto Alegre, v. 4, n. 1, p. 61-91, jan./jun. 2010. 
LISIANE KOLLER LECZNIESKI - Objetos relacionais ameríndios...

como costumam dizer, moldando-o e proporcionando-lhe a forma desejada. Os objetos são "alisados" com rochas especiais e a peça, ainda úmida, está pronta para receber os grafismos executados pelas artistas com uma precisão e rapidez impressionantes. Utilizando apenas um cordão fiado com caraguatá (uma bromélia da região, Aloe barbadensis Mill) as ceramistas executam uma verdadeira dança com dedos e mãos, delineando delicados sulcos na argila, e assim os desenhos vão surgindo, como que por magia, em finas linhas que imprimem um sutil relevo nas peças. Estes sulcos serão posteriormente pintados com um barro branco, denominado "caulim"17 - são as linhas brancas que contornam as áreas coloridas. As peças são então cuidadosamente colocadas em um buraco escavado no chão, sobre o qual se ergue uma fogueira com lenhas especiais.

Terminada a queima cobrem áreas pré-determinadas dos desenhos com a tinta do "pau-santo" (Kielmeyera coriacea), uma resina negra, retirada da árvore de mesmo nome e que dá uma textura vitrificada às peças. Partes do tronco da árvore são cortados em pedacinhos que são fervidos com água, em um grande recipiente. Aos poucos a resina vai saindo "do corpo da árvore" e subindo à superfície da água, quando é retirada, esfriada e moldada em forma de bastão, para facilitar a aplicação nas peças. Este processo é muitas vezes realizado longe das aldeias, em lugares longínquos da Reserva, onde as árvores são encontradas, sendo também o único trabalho, na arte cerâmica, que admite auxílio masculino. A pintura com o pau-santo é efetuada nas peças recém saídas do forno, para que a resina derreta no contato com a peça ainda quente. O aspecto negro envernizado do pausanto contrasta com o colorido opaco das "tintas de terra", todas em tons pastel de vermelho, amarelo e verde, que são por fim aplicadas nas peças com o auxílio dos dedos 18 .

Os motivos gráficos são caracterizados especialmente por

\footnotetext{
17 Uma tinta que, segundo afirmam, é mais difícil de encontrar e de extrair, uma vez que as "minas" se encontram "enterradas" nas margens de determinados córregos da Reserva.

18 Graziato observa que nas coleções recentes, ao branco do caulim, ao preto do pau-santo e ao vermelho da hematita (típicos das peças mais antigas) soma-se uma "grande variedade de barros coloridos encontrados na Serra da Bodoquena, conferindo às peças originalidade em relação à produção de outras etnias. Foram introduzidas cores - como os ocres, e os amarelos, oriundos de rochas ferruginosas e filíticas, compostas essencialmente por minerais do grupo das micas, o que determina seu aspecto brilhante" (GRAZIATO, 2008, p. 51).
} 
LISIANE KOLLER LECZNIESKI - Objetos relacionais ameríndios...

espirais, volutas, filigranas e degraus interligados que são organizados de infinitas maneiras. Nas peças predominam dois estilos - um curvilíneo, outro geométrico - que são articulados entre si e cuja padronização é diferenciada de acordo com o lugar em que é aplicado. Nos vasos, por exemplo, nota-se uma distinção dos desenhos elaborados no gargalo ou "pescoço", mais geométricos, e aqueles do bojo ou "corpo" do vaso, mais curvilíneos - expressão que, diga-se de passagem, encontra paralelo nas pinturas corporais, onde nota-se uma tendência a diferenciar, em termos estilísticos, as pinturas faciais daquelas efetuadas em outras partes do corpo.

Todos os desenhos apresentam, no entanto, um traço característico de espelhamento, no qual o desenho é apresentado como que confrontando um duplo seu19. Estes efeitos espelhares ou de duplicação caracterizam, de fato, diversos padrões gráficos ameríndios. Outra característica dos grafismos kadiwéu (e ameríndios, em geral) são os efeitos de figura e fundo, que possibilitam que se veja os desenhos em duas perspectivas distintas, em positivo e em negativo, que não deixa de ser uma outra forma de desdobrar a representação. A representação dos desenhos através de formas recursivas (repetidas ad infinitum), também marca os grafismos kadiwéu, remetendo a uma continuidade latente, virtual, notavelmente visível quando o padrão gráfico é interrompido a meio caminho, nas bordas, sugerindo uma continuação que extrapola suas margens 20 .

Estas imagens, evocando espelhamento e duplas faces, por um lado, e a idéia de recursividade e abertura para o exterior, por outro, encontram paralelos tanto na concepção relacional dos objetos (como mediadores, elos apenas, entre duas partes) quanto nas diversas práticas sociais do grupo, em especial as estabelecidas com alteridades (internas e externas ao grupo), onde as relações se expressam sempre de forma dual e confrontada - sendo simultaneamente procuradas e

\footnotetext{
19 Focando as análises nas pinturas corporais, sobretudo faciais, Lévi-Strauss sugere que este "desdobramento da representação é função de uma teoria sociológica do desdobramento da personalidade", pois "no pensamento indígena, o ornato é o rosto, ou antes, ele o cria. É ele que lhe confere seu ser social, sua dignidade humana, sua significação espiritual. A dupla representação do rosto, considerada como processo gráfico, exprime um desdobramento mais profundo e mais essencial: o do indivíduo biológico 'estúpido' e do personagem social que ele tem por missão encarnar (LÉVI-STRAUSS, 1996, p. 295).

20 Ver Lévi-Strauss (2001); Lagrou (2007b), entre outros.
}

Espaço Ameríndio, Porto Alegre, v. 4, n. 1, p. 61-91, jan./jun. 2010. 
LISIANE KOLLER LECZNIESKI - Objetos relacionais ameríndios...

repelidas, como veremos. Em outras palavras, as formas de representar os desenhos repercutem ou se entrelaçam nas formas de agir, configurando assim a vida social dos objetos e as dinâmicas sociais que os movimentam, envolvem e fazem circular. Como vimos, os Kadiwéu referem a cerâmica não apenas como um símbolo tangível da sua "cultura" e "nobreza", herdadas dos antigos, mas como objetos que, para além de simplesmente representar e evocar uma memória, são formas de agir no mundo. São feitos para criar laços e estabelecerem, efetivamente, conexões, seja com os parentes do passado, com alteridades externas ou internas.

Esta ampla gama de significados, assim como as dinâmicas e formas de agência que exercem, passam totalmente despercebidas, ou são totalmente desconsideradas pela sociedade "branca" envolvente, como o exemplo das transações empreendidas pela Rede Globo deixa claro. Na novela Alma Gêmea os objetos foram dissociados não apenas de seu contexto de origem como também dos significados que os definem e fazem circular. Despidos de identidade, acabaram por desempenhar uma função justamente oposta àquela para o qual foram, especificamente, projetados, dado que, como afirmam, é para os "brancos" que eles são, especialmente, produzidos. Nesse processo, perderam todo o potencial relacional que lhes é atribuído e ao qual devem sua existência21.

O efeito espelhar da cerâmica, nesse sentido, ultrapassa o nível puramente estilístico e abre uma reflexão sobre o lugar do diálogo intercultural e do respeito às diferenças, na nossa sociedade. A cerâmica como instrumento de auto-reflexividade, como um espelho levado à nossa face social, refletindo a imagem que os indígenas fazem da nossa sociedade (NOVAES, 1993). O antropólogo não mais como único sujeito de conhecimento e o "nativo" não mais como um objeto passivo deste saber (DERRIDA, 2005).

21 Trata-se de uma dimensão intangível, de objetos tangíveis, que deveria ser considerada e avaliada quando se discute questões relacionadas aos "conhecimentos tradicionais" (AIKAWA, 2003), mais especificamente, àqueles que navegam pelas águas turvas dos chamados direitos de "propriedade intelectual" e/ou "direitos autorais", como veremos mais adiante. 
LISIANE KOLLER LECZNIESKI - Objetos relacionais ameríndios...

\section{A arte Kadiwéu de cativar os outros}

Os Kadiwéu dizem que as pinturas corporais, assim como as cerâmicas, são feitas especialmente para enfeitar. As pinturas, as pessoas, as cerâmicas, "as casas dos brancos"22. Destacam-se, nesta produção, vasos minuciosamente decorados e imponentes, alguns medindo mais de um metro de altura. Os objetos de cerâmica são produzidos, e seu conhecimento repassado, exclusivamente pelas mulheres. Além de ser uma importante fonte de renda, a cerâmica é referida, por homens e mulheres, como sendo um grande símbolo da sua "cultura" e do "sistema do índio". Os desenhos são definidos como "bens valiosos", sobretudo pelo fato de serem "feitos do mesmo jeito como faziam nossos avós kadiwéu". Recorrentemente associados à "sabedoria dos antigos" e lembrados como "herança" dos antepassados, os desenhos e as cerâmicas são concebidos como uma "marca kadiwéu" e entendidos como motivo de orgulho coletivo. Nesse sentido pode-se afirmar que constituem importantes símbolos de identidade étnica e grupal23.

Poucas vezes vi as cerâmicas enfeitando suas próprias casas. Em geral as ceramistas reservam um aposento específico para armazenar as peças prontas e as matérias-primas utilizadas na sua produção, bem como trabalhar nos dias de chuva. Noutros dias, a cerâmica é feita no pátio das casas.

Muitas mulheres explicam o fato de terem poucas crianças argumentando que, caso contrário, o trabalho na cerâmica seria prejudicado. Segundo uma mãe, "criança precisa ser vigiada o tempo todo, senão já come qualquer porcaria do chão", "precisa ser cuidada de perto", "precisa de atenção". O tempo e o trabalho consumido na produção cerâmica são sempre enfatizados, também como uma forma de agregar valor às peças (provavelmente recorrendo a elementos que, sabem, repercute no imaginário de seus principais interlocutores, na maioria brancos). A cerâmica nunca foi descrita, porém, em termos de sobrecarga de trabalho, pelas mulheres que a produzem.

22 A confecção de objetos para vender para outros grupos é uma prática antiga, como pode-se concluir pelos escritos de diversos autores, entre eles Boggiani (1975).

23 Tanto as mulheres kadiwéu quanto as mulheres de outras etnias (inclusive descendentes de criados) que vivem na aldeia podem ser, e são, ceramistas. 
LISIANE KOLLER LECZNIESKI - Objetos relacionais ameríndios...

Trata-se, sem dúvida, de uma atividade com considerável investimento de tempo e trabalho, sobretudo se considerarmos que muitas mulheres não somente coletam as matérias-primas e confeccionam, desenham e pintam as peças, como também comercializam sua produção, tanto dentro quanto fora da aldeia, nas cidades. Com menos frequência, comerciantes vão à aldeia para adquirir as peças que serão comercializadas nas lojas de cidades turísticas da região, como as requintadas butiques da cidade de Bonito, onde circulam diariamente estrangeiros das mais diferentes nacionalidades. Neste lugares, as peças podem valer mais de vinte vezes o preço pago na aldeia.

Algumas mulheres também viajam para vender sua cerâmica, em geral para cidades vizinhas, mas que exigem ficar fora da aldeia por dias, às vezes. Nas cidades se deparam com situações muito distintas das que vivem na aldeia e que requerem, como uma delas observou, um "espírito de aventura". Vale destacar, neste contexto, a viagem realizada por seis ceramistas à Berlim, em 1998, com o objetivo de conhecer e inaugurar um complexo de edifícios residenciais ornamentado com desenhos por elas elaborados e impressos em placas cerâmicas industrializadas ${ }^{24}$ que cobriram paredes e fachadas.

Tanto as mulheres quanto os homens falam do "valor", do "trabalho" e das particularidades envolvidas na produção destes objetos que todos desejam ver espalhados "mundo afora". As pessoas remarcam que as cerâmicas kadiwéu podem ser encontradas nas casas de pessoas importantes e nos lugares mais distantes, como museus, "até na Europa"25. Esta idéia da visibilidade Kadiwéu através da cerâmica é condensada no comentário de um velho senhor que, explicando orgulhoso que "os Kadiwéu tem representação em toda parte do mundo", contou que "até o Julio Iglesias tem um grande vaso kadiwéu"

24 A viagem foi uma forma de pagamento das artistas cujos trabalhos foram escolhidos pelo escritório Brasil Arquitetura (SP) - vencedor do concurso entre arquitetos latino-americano patrocinado pela prefeitura de Berlim - para a execução do projeto de renovação urbana no "Bairro Amarelo" (Gelbes Viertel) em Berlim-Hellersdorf. Trata-se de um complexo de edifícios cuja fachada (antes idêntica e que, segundo me contaram, dificultava a diferenciação pelos moradores) foi redecorada com os azulejos com padrões kadiwéu. Participaram do concurso por intermediação do advogado Alain Moreau. Na ocasião, foi realizado um concurso interno no qual participaram mais de 90 ceramistas (seis delas tiveram seus desenhos escolhidos).

25 Referindo-se a museus em Praga, Berlim, Roma, Rio de Janeiro, entre outros, que apresentam coleções da arte kadiwéu, de diferentes épocas, em seu acervo.

Espaço Ameríndio, Porto Alegre, v. 4, n. 1, p. 61-91, jan./jun. 2010. 
LISIANE KOLLER LECZNIESKI - Objetos relacionais ameríndios...

em sua sala26. "Gente importante", fez questão de frisar, "que sabe que Kadiwéu existe".

Imagem 2: Ceramistas kadiwéu em Berlim.

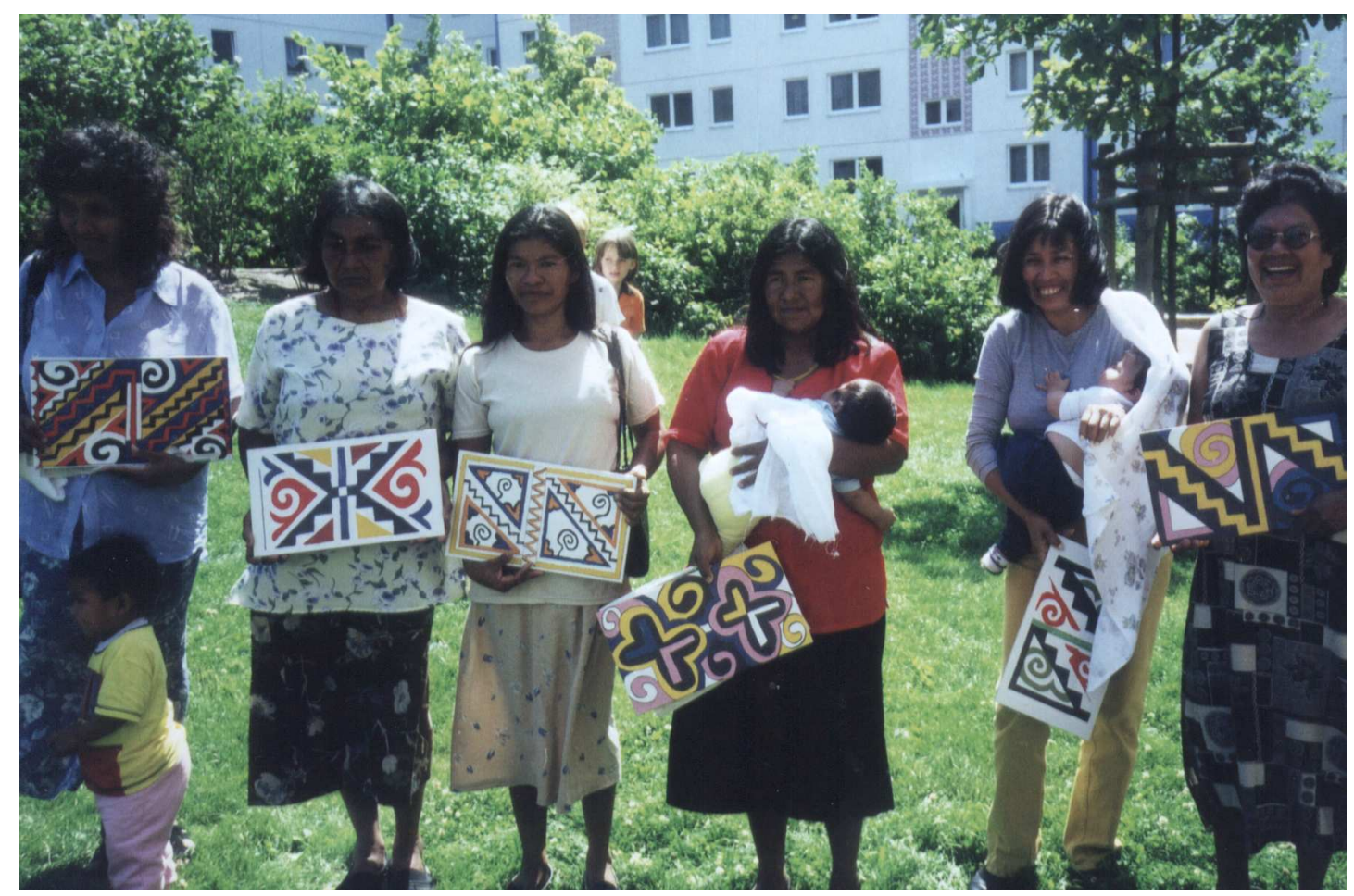

Foto: Pilar de Melo Mandelik Pelho, colaboradora do projeto de parceria pecuária com Kadiwéus e de pecuária indígena em regime familiar, vinculados na fazenda Namocoli.

Estas noções revelam, como se vê, uma expectativa de intencionalidade em relação aos objetos. Uma aspiração de se relacionar, de ser conhecido e reconhecido como grupo cultural distinto, através dos objetos que produzem. Feitos "para enfeitar as casa dos brancos", os vasos (e demais peças cerâmicas) são concebidos como um meio de atingir este ideal e de cativar, pela beleza, alteridades que são vistas como potencial, ou efetivamente, perigosas.

E os perigos não são poucos. Existe uma gama de situações

26 A informação lhe fora passada por uma parente, moradora da cidade, que constatara o fato via televisão, assistindo uma entrevista que o cantor dera em sua própria casa. 
LISIANE KOLLER LECZNIESKI - Objetos relacionais ameríndios...

relacionadas à chamada questão dos direitos tradicionais indígenas, por exemplo, que não tem sido devidamente apreciada. Mesmo sendo uma defensora da liberdade de acesso às diferentes formas de conhecimentos e reticente, portanto, às soluções que restringem o problema a uma questão de "propriedade intelectual", penso que certos contextos exigem uma posição não proprietária, mas tampouco passiva. Nenhuma sociedade é estática e congelada no tempo e as relações entre grupos culturalmente diversos é uma realidade crescente. A valorização dos "artigos étnicos", na economia global, nos coloca problemas similares a este evidenciado pela novela. Existem casos de indústrias (têxteis, de revestimentos cerâmicos, etc.) por exemplo, que sabidamente utilizam padrões gráficos indígenas em suas linhas de azulejos e pisos e estes produtos são frequentemente anunciados em termos de um diferencial ("linha étnica") que, por si só, já agrega valor aos produtos. São comuns, nestes contextos, argumentos de que a empresa "negociou" os devidos direitos para reproduzir os desenhos e que os "interessados" foram devidamente pagos. Um caso ainda mais complexo é o de artistas que reproduzem padrões étnicos em suas obras ou mesmo re-elaboram formas que, como vimos, podem, mesmo que virtualmente, integrar o repertório gráfico de determinado grupo 27 . Questões complexas mas que, como argumentou uma jovem ceramista, "acontecem todos os dias e agente não pode fazer nada". Referindo-se aos casos envolvendo "imagens do Mickey, Mac Donald... ", argumenta que, quem usar, vai processado, vai preso até. "Mas se é índio, ninguém se importa".

O fato de os "objetos" serem postos a circular no mercado globalizado não deveria lhes retirar o poder relacional inerente, ao contrário, poderia ser usado para potencializá-lo, como uma forma de incluir o Outro, respeitando as diferenças. Esta lógica relacional se choca, no entanto, com a lógica do capital, como vimos na crítica pontual de dona Matexua. Um olhar distanciado e que não deixa de ir direto a um dos pontos mais críticos das sociedades contemporâneas: a super-produção e acumulação de objetos, às custas das relações (com a natureza, por exemplo), que são "levadas pelo vento".

27 Como observa Siqueira Júnior (1992, p. 53), "os desenhos kadiwéu são variados e nunca se repetem; mesmo assim, eles marcam o estilo kadiwéu". 
LISIANE KOLLER LECZNIESKI - Objetos relacionais ameríndios...

A atribuição de "propriedade", por outro lado, parece mais complicar do que solucionar os problemas. Embora se orgulhem de suas produções pessoais, as artistas kadiwéu resistem à idéia de uma autoria exclusiva, e seu orgulho é sempre compartilhado, nunca visto como resultado de um esforço puramente individual ou pessoal.

\section{Da autoria à autoridade}

As questões relacionadas aos direitos autorais e de propriedade intelectual são especialmente complexas quando se trata de definir o contexto dos saberes tradicionais indígenas. A própria definição destes saberes enquanto propriedade, mesmo que coletiva, já coloca problemas, visto não dar conta, como no caso kadiwéu, de uma série de contextos e situações específicas. A descrição e análise das formas como estas noções são articuladas em contextos específicos pode ser, no entanto, esclarecedora.

Certa vez, frente a minha sugestão de que assinasse seu nome no magnífico vaso que me dera de presente, uma ceramista explicou que "aquele vaso tinha trabalho de muita gente" e não somente dela, a ceramista que o produziu. Se assinasse seu nome no vaso estaria "desconsiderando", segundo disse, "o trabalho de muitas gerações": "É claro que fui eu quem fiz este vaso, mas a sabedoria que me levou a fazê-lo vem de longe, da minha avó, da avó da minha avó e assim vai (...). Sem estas referências eu não saberia nem por onde começar". Colocar o nome significa, neste contexto, imprimir uma "marca pessoal" em algo que é visto como herança de um aprendizado. Uma marca que "desconsidera" e "desvaloriza" a "memória dos avós kadiwéu".

$O$ fato de não querer assinar o nome no objeto não significa, entretanto, ausência de distinções internas quanto à qualidade do acabamento e mesmo beleza dos objetos e pinturas produzidos. Ao contrário, algumas ceramistas distinguem suas cerâmicas das produzidas por outras ceramistas, enfatizando o uso de determinada madeira, considerada especial, na queima de suas obras; ou a leveza das mãos no movimento do cordão com o qual desenham; ou o cuidado com as tintas e com a pintura dos detalhes, entre outros critérios. $\mathrm{O}$ 
LISIANE KOLLER LECZNIESKI - Objetos relacionais ameríndios...

aparente "descaso" para com a autoria nos remete, na verdade, a uma forma diversa, se comparada aos moldes ocidentais, de conceber e lidar com a idéia de autoria e propriedade. Os objetos não são, de forma alguma, vistos como anônimos. Eles são muito bem identificados e reconhecidos, com a diferença de que a autoria não se restrinja ao indivíduo. Todos, homens e mulheres reconhecem e valorizam o investimento da pessoa naquela obra, seu "capricho", algumas ceramistas desfrutando um prestígio maior que outras. E os frutos (financeiros, relacionais, etc.) advindos dos objetos (vendidos, trocados, presenteados, etc.) não são vistos, nesse contexto, como bens que devam ser distribuídos igualitariamente entre toda coletividade, sem distinções.

Simultaneamente, enquanto detentores de um saber herdado dos antepassados e enquanto expressão deste saber, os desenhos são recorrentemente apresentados não em termos individuais, mas sempre relacionais. Esta natureza relacional dos desenhos parece tão forte a ponto de contagiar os objetos nos quais são aplicados, dotando-lhes também de um potencial relacional, agora sim voltado para alteridades externas, no caso, os brancos 28 .

O modelo da "propriedade intelectual" que orienta os debates em torno dos "conhecimentos tradicionais" e do "patrimônio imaterial" deve ser confrontado, como nota Coelho de Souza "com o significado que essas produções têm em seus contextos nativos, com as práticas e relações de que são fruto e que elas vêm incorporar" (2005, p. 14). É preciso sustentar, por outro lado, a diferença entre a "cultura indígena" tal como emerge da prática antropológica e tal como emerge dos embates identitários em jogo na política da propriedade intelectual, como adverte Coelho de Souza (2005).

Como argumenta Cesarino (2009), "onde colocamos a autoridade, os pensamentos ameríndios postulam a alteridade e a multiplicidade" e "para compreendê-los, é necessário deslocar a matriz do processo de criação para outro plano que o do ego, do sujeito autocentrado, da autoria individual e fechada". Os ameríndios, como enfatiza o autor,

28 Ao contrário do observado em outros contextos ameríndios (LAGROU, 2007b; BARCELOS NETO, 2002), a relação entre os objetos e alteridades externas não é vista como centrípeta, mas centrífuga. Os Kadiwéu não dizem, por exemplo, que os desenhos foram obtidos de outros povos ou trazidos de fora do grupo. 
LISIANE KOLLER LECZNIESKI - Objetos relacionais ameríndios...

"falam outras linguagens, imaginam outras literaturas, têm em outras matrizes de pensamentos e se colocam na arena pública seguindo outras premissas" (CESARINO, 2009, p. 6-7), ainda ignoradas e distintas das que guiam nossa sociedade.

\section{Fazendo arte: o grafismo ameríndio e a arte das relações}

É comum ouvirmos críticas quanto ao uso que os índios fazem dos objetos, especialmente aqueles que ganharam dos brancos. Um funcionário da FUNAl, por exemplo, exclamou com indignação: "Eles fizeram de tudo para conseguir esses livros, pediram, negociaram, exigiram, investiram na sua obtenção e agora, olha só, estão ali, atirado às traças". A importância do investimento ameríndio nas práticas de produção de objetos (materiais e imateriais) é frequentemente mal compreendida pelo pensamento ocidental.

A produção, circulação e obtenção de objetos envolve conhecimentos, investimentos e técnicas que, no entendimento dos índios, geram não somente "objetos" mas também outras coisas, sobretudo, relações. Percebe-se aí um eco do caráter essencialmente relacional do divisor Eu/Outro, há bastante tempo anotado na etnologia americanista. Viveiros de Castro (2004) sugere que a antropologia ameríndia - o perspectivismo - parece projetar uma imagem de pensamento radicalmente diversa da nossa no que se refere ao conceito de relação. Várias etnografias ameríndias têm destacado, por exemplo, a alteridade como constitutiva nos modos ameríndios de socialidade e não, simplesmente, como uma posição contrastiva em face da qual a identidade é produzida. Uma ontologia relacional na qual parece ocorrer uma interpenetração mutuamente constitutiva entre Eu e Outro29.

Este aspecto tem sido também anotado nas análises antropológicas dedicadas, nas últimas décadas, a aprofundar os estudos da relação entre grafismos, estética, organização social e cosmologia no mundo ameríndio ${ }^{30}$. Um aspecto fundamental destacado em

29 Viveiros de Castro (1996 e 2004), Vilaça (1992), Fausto (2001), entre outros.

30 Como Guss (1990); Vidal (1992); Gallois (2002); Lopes da Silva e Farias (1992); Müller (1992 e 1993); Gow (1999 e 2001); Barcelos Neto (2002); Van Velthem (2003); Lagrou (2007a e 2007b), Macedo (2007), entre outros. 
LISIANE KOLLER LECZNIESKI - Objetos relacionais ameríndios...

praticamente todos estes estudos é a dimensão relacional e comunicativa dos desenhos e dos grafismos ameríndios. Mais que representar algo, os grafismos, pinturas e desenhos exercem, efetivamente, uma agência sobre as pessoas e sobre os seres do universo ${ }^{31}$. Como notam alguns autores, o grafismo ameríndio é pensado como uma forma de comunicação, em especial com seres de outros domínios cosmológicos, onde observa-se um sistema de troca, guerra e predação, estabelecidas com tais seres (VIDAL, 1992; GOW, 1999 e 2001; BARCELOS NETO, 2002; VAN VELTHEM, 2003; LAGROU, 2002, 2007a e 2007b).

Num processo similar, mas inverso, ao observado por Barcelos Neto (2002), entre os Wauja (de fala aruake, do Xingu, Mato Grosso, Brasil, onde os grafismos agem e interferem nas formas de interações com seres extra-humanos), a arte kadiwéu parece configurar-se como veículo que permite um contato mais pacífico e, em certo sentido, domesticado, não com extra-humanos, mas humanos percebidos como radicalmente diferentes. Ao invés da comunicação se dar com seres de outros domínios cosmológicos (animais e espíritos, como no caso Wauja), dá-se com seres considerados de outro mundo, como sugerem suas recorrentes menções ao "mundo dos brancos". A arte aparece, neste contexto, como um canal comunicativo em aberto, uma "língua" relativamente comum, ou um meio mais viável de acesso ao mundo destes seres estranhos que, como remarcou a mãe da pretendente a atriz, parece até que branco "só enxerga índio assim, se faz coisa bonita. Senão, olha, mas nem vê, já esquece".

E motivos não faltam que sustentem esta concepção, possivelmente forjada, e espelhada, ao longo da história do contato. Os objetos do mundo ocidental sempre tiveram, como bem se sabe, um papel mediador crucial nesse processo, sendo, muitas vezes espalhados pelos brancos na floresta, como primeiros sinais de aproximação. Também o fascínio especial historicamente demonstrado pelos objetos indígenas e pelas expressões artísticas indígenas, certamente também exerce um peso na formulação destas concepções nativas. Acontece que

31 Como nota Lagrou, "Esta relação não envolve uma reversibilidade de posições em que sujeito significa agência e objeto passividade, mas uma intersubjetividade em que ambas as posições apresentam as qualidades de agência e de subjetividade" (LAGROU, 2002, p. 36). 
LISIANE KOLLER LECZNIESKI - Objetos relacionais ameríndios...

o significado desta interação através de objetos não é, definitivamente, o mesmo, para índios e brancos.

Frequentemente vistos meramente em sua dimensão estética, os significados mais profundos destes objetos são, muitas vezes, ignorados justamente por aqueles a quem os objetos são, como no caso kadiwéu, "especialmente" produzidos.

O contexto Wayãpi (de fala tupi-guarani, Guiana Francesa) nos apresenta ainda uma outra variação sobre este mesmo tema. Segundo Macedo (2007), o grupo se apropria dos padrões gráficos que identificam como "dos brancos" - como flores, personagens de histórias, letras do alfabeto, filmes, etc. - visando, com isso, "uma forma de constituir com esses outros, os 'brancos' - os paraisiko (franceses) e os karaiko (brasileiros) - uma boa relação" (MACEDO, 2007, p. 70).

Uma "estética da pacificação", como sugere Lagrou, analisando o lugar das miçangas no mundo Kaxinawá. Partindo da constatação, recorrentemente anotada, de que muitas sociedades ameríndias situam no exterior fonte de inspiração artística e cultural, Lagrou observa que este material vindo do exterior é absorvido, elaborado, processado e transformado pelos ameríndios, constituindo-se, nesse processo, como parte da própria identidade grupal. O tratamento dado à miçanga revela uma "estética da pacificação" que pode ser lida, segundo a autora, como uma manifestação específica de uma "estética de pacificação do inimigo" (LAGROU, 2007a).

As relações dos Kadiwéu com a alteridade são expressas, recorrentemente, em uma via de mão dupla: guerra e diplomacia, predação e cuidado, absorção e repulsão. O equivalente mais próximo das miçangas, no caso Kadiwéu, seja talvez o cavalo, capturado logo no início da colonização, prontamente incluído na mitologia e domesticado, sobretudo como arma de guerra32. Mas não se trata, como se vê, de uma "pacificação artística" aos moldes daquela processada pelos Kaxinawa através das miçangas. Se sua incorporação foi artística, ela se

32 Darcy Ribeiro, por exemplo, transcreve um mito onde a mancha da lua é apresentada como um cavalo (RIBEIRO, 1980). Colini lembra o sacrifício e sepultamento do cavalo junto ao seu dono, quando da morte deste, observando que "a contragosto vendiam algum, tanto valor lhes davam. Tinham um cuidado especial por aqueles que destinavam à guerra e não teriam consentido em cedê-los ou vendê-los a nenhum preço" (COLINI, 1975a, p. 270). 
LISIANE KOLLER LECZNIESKI - Objetos relacionais ameríndios...

refere, sobretudo, a uma arte guerreira. A via artística e diplomática nas relações com os outros, os Kadiwéu a trilham através da arte gráfica, sobretudo da cerâmica. Uma "estética da pacificação" que expõe, de forma notável, o caráter eminentemente relacional e comunicativo atribuído à arte no mundo ameríndio.

\section{Entre a atração e a repulsão}

Guerra e diplomacia são (e historicamente foram) ingredientes fundamentais da política kadiwéu, como pode-se constatar na bibliografia sobre o grupo. As relações externas kadiwéu com os diferentes agentes da sociedade ocidental adquirem formas de interação que, frequentemente, remetem ao mundo das artes e enfatizam, de forma curiosa, ora a atração, ora a repulsão. A produção e comércio de cerâmica, por exemplo, integra a primeira forma de relação, impulsionada pela noção de beleza que, segundo os Kadiwéu, é buscada pelos estrangeiros. Segundo os Kadiwéu, é pela sua "beleza" e "nobreza" (herdadas dos antepassados) que estes objetos cativam os outros. Por isso suas aldeias estão sempre abertas àqueles que buscam adquirir suas cerâmicas 33 .

A idéia de repulsa, por outro lado, fica evidente em diversas performances narrativas como, por exemplo, as contínuas histórias sobre "os corridos", como designam o infindável número de pessoas e grupos expulsos da aldeia (que "saíram corridas", como dizem), e sobre as quais contam histórias às vezes cômicas, outras vezes dramáticas. A beleza kadiwéu que atrai o olhar estrangeiro tem como contrapartida, de fato, o clima de tensão que permeia praticamente todas as relações kadiwéu com o mundo externo. Uma desconfiança cultivada ao longo das trágicas experiências vividas no encontro colonial e com a sociedade nacional, e que são cotidianamente alimentadas nas lembranças

33 Certa vez, visando prolongar a vida dos vasos que comprara, sugeri a uma ceramista que me desse uma amostra de tintas para retocar as peças, caso fosse necessário. Relutante, explicou que não bastaria retocar a tinta porque "o vaso envelhece, perde o viço, assim como as pessoas!". Sugeriu que "quando o vaso ficar velho a senhora volta aqui, faz uma visita e já aproveita para levar um outro vaso, ainda mais lindo que este". A graça da cerâmica, assim como as relações que ela engendra, depende de sua constante reprodução e renovação. 
LISIANE KOLLER LECZNIESKI - Objetos relacionais ameríndios...

constantes sobre o passado guerreiro e heróico do grupo, assim como na mitologia, onde a figura altamente ambivalente do estrangeiro é marcante (KOLLER LECZNIESKI, 2005). Percebe-se, nesse processo, um entrelaçamento particular entre ideais éticos e estéticos - entre arte, mito e vida social - desenhado, literal e figuradamente, através de um diálogo, sempre buscado, entre "os meios através dos quais a arte se expressa e o sentimento pela vida que os estimula", como bem descreve Geertz (1999, p. 148).

Em um contexto de luta pela manutenção de suas terras, constantemente ameaçadas, os Kadiwéu manifestam uma compreensão comunicativa e relacional da arte, distanciada da ideia ocidental centrada no valor estético contido, stricto sensu, nos objetos. Recorrem ao campo das artes como forma de cativar a empatia e simpatia externas e, quem sabe assim, obter reconhecimento de sua existência enquanto grupo diverso e com direito a continuar existindo ${ }^{34}$. A arte aparece, nesse contexto, como uma praxis social e política e não como uma expressão unicamente estética, desinteressada ou isolada do contexto no qual ocorre. A dimensão estética remete e se articula a uma dimensão ética bem determinada, que visa tecer, por meios pacíficos e (vistos como) simétricos, relações sociais potencial e historicamente conflitivas e assimétricas.

Constantemente inserida num universo de relações, esta praxis relacional, alimentada por objetos (observada em diversos grupos ameríndios) comunica significados e revela objetivos claramente determinados que, como observam Bregalda e Chagas (2008), além de nos informar sobre modos específicos de "de criar, fazer e viver", devem ser objeto de conhecimento da sociedade e reconhecimento pelos poderes públicos 35 (BREGALDA e CHAGAS, 2008, p. 60). Enquanto práticas e concepções de mundo marcadamente distintas, devem ser reconhecidas como "intangible cultural heritage" (UNESCO - fonte). Embora esta possa parecer uma questão menor, frente ao drama cotidianamente vivido por diversos grupos indígenas que lutam pelos

\footnotetext{
34 No passado, como no presente, os criados se destacam na apologia da nobreza e da bravura kadiwéu, assim como na transmissão dos mitos e histórias dos antigos.

35 Analisando o lugar do artesanato na vida social kaingang (grupo de fala jê, sul do Brasil), as autoras destacam a sua importância como articuladores de relações que, além de proporcionarem a constituição da diversidade grupal, agem como "via de produção e manutenção" de sua ontologia.
} 
LISIANE KOLLER LECZNIESKI - Objetos relacionais ameríndios...

direitos mais básicos à existência ${ }^{36}$, trata-se, como procurei mostrar neste artigo, de uma forma sutil mas incisiva de minar, desqualificar e predar a diferença e os direitos dos povos tradicionais, no mundo globalizado.

Uma questão que se coloca hoje para os Kadiwéu, como para muitos outros grupos indígenas, é a de como continuar relacionando-se através da arte, eixo relacional central no mundo ameríndio, sem que sua particularidade se dilua nos processos mercantis das sociedades regidas pelo poder do capital. O respeito pela diferença vem, entre outras coisas, do entendimento que se tem dela, e espero que esta reflexão contribua para melhor compreendermos o ponto de vista indígena, sobretudo o lugar central da arte enquanto articuladora de relações sociais e a dimensão eminentemente relacional dos objetos ameríndios.

\section{Referências bibliográficas}

AIKAWA, Noriko. Visión Histórica de la Preparación de la Convención Internacional de la UNESCO para la Salvaguardia del Patrimonio Cultural Inmaterial. Museum Internacional. Patrimonio Inmaterial. Paris, n. 221-222, p. 140-155, 2003. Disponível em: http://portal.unesco.org/culture/en/ev.php . Acesso em: 5 set. 2006.

ALMEIDA SERRA, Ricardo F. de. Parecer sobre o aldeamento dos índios Uiacurús e Guanás com a descripção dos seus usos, religião, estabilidade e costumes. Revista do Instituto Histórico e Geográfico Brasileiro. Rio de Janeiro, v. 7. p:196-208, 1845.

AZARA, Felix de. Viajes por la América Meridional. Madrid: Espasa-Calpe S/A, 1969. (Colección Austral).

BALDUS, Herbert. Introdução. In: BOGGIANI, Guido. Os Caduveos. São Paulo: Editora da Universidade de São Paulo, 1975. p. 11-46.

BARCELOS NETO, Aristóteles. A arte dos sonhos: uma iconografia ameríndia. Lisboa: Museu Nacional de Etnologia/Assírio \& Alvim, 2002.

BOGGIANI, Guido. Os Caduveos. São Paulo: Editora da Universidade de São Paulo, 1975.

36 Como o caso dramático dos índios Xukuru, por exemplo, vivendo sob constante perseguição e ameaças desde que tiveram suas terras demarcadas, um drama invisível aos meios de comunicação de massa. Ver http://baixosaofrancisco.blogspot.com/2009/05/cacique-do-povo-xukuru-e-condenado.html .

Espaço Ameríndio, Porto Alegre, v. 4, n. 1, p. 61-91, jan./jun. 2010. 
LISIANE KOLLER LECZNIESKI - Objetos relacionais ameríndios...

BREGALDA, Damiana; CHAGAS, Miriam de Fátima. A diversidade no artesanato kaingang: um passaporte na cidade? In: Prefeitura Municipal de Porto Alegre/ Secretaria Municipal de Direitos Humanos e Segurança Urbana/ Coordenação de Direitos Humanos/ Núcleo de Políticas Públicas para os povos indígenas. Povos Indígenas na Bacia Hidrográfica do Lago Guaíba: Porto Alegre, Rio Grande do Sul, Brasil. Porto Alegre: Prefeitura de Porto Alegre, 2008. p. 51-61.

CABEZA DE VACA, Alvár N. Naufrágios e comentários. Porto Alegre: L\&PM, 1999.

CASTELNAU, Francis De. Expédition dans les parties centrales de l'Amérique du Sud (1843-47). Paris: Chez P. Bertrand, 1850.

CESARINO, Pedro N. Os poetas. Folha de São Paulo, São Paulo, 18 jan. 2009. Caderno Mais! p. 6-7. Disponível em: http://www1.folha.uol.com.br/fsp/mais/fs1801200909.htm. Acesso em: 27 jun. 2009.

COELHO DE SOUZA, Marcela. A propriedade da cultura: transformações kisêdjê (suyá). 2005. Projeto (Pós-Doutorado em Antropologia Social) - Núcleo de Transformações Indígenas, Programa de Pós-Graduação em Antropologia Social do Museu Nacional, UFRJ, [2005].

COLINI, Giuseppe A. Notícia histórica e etnográfica sobre os Guaicurú e os Mbayá. In: BOGGIANI, Guido. Os Caduveos. São Paulo: Editora da Universidade de São Paulo, 1975a. p. 249-307.

Prefácio de G. A. Colini. In: BOGGIANI, Guido. Os Caduveos. São Paulo: Editora da Universidade de São Paulo, 1975b. p. 47-62.

DERRIDA, Jacques. A escritura e a diferença. São Paulo: Perspectiva, 2005.

FAUSTO, Carlos. Inimigos fiéis. São Paulo: Edusp. 2001.

GALLOIS, Dominique. Expressão gráfica e oralidade entre os Wajãpi do AmapáBrasil. Boletim do Museu do Índio, Rio de janeiro, n. 9, p. 5-67, 2002.

GEERTZ, Clifford. O saber local. Petrópolis: Editora Vozes, 1999.

GOW, Peter. Piro designs: painting as meaningful action in an Amazonian Lived World. Journal of the Royal Anthropological Institute, Londres, v. 5, n. 2, p. 229246, 1999.

2001.

An Amazonian Myth and its History. Oxford: Oxford University Press,

GRAZIATO, Vânia Perrotti Pires. Cerâmica Kadiwéu: processos, transformações, traduções: uma leitura do percurso da cerâmica Kadiwéu do século XIX ao XXI. 2008. 
LISIANE KOLLER LECZNIESKI - Objetos relacionais ameríndios...

126 f. Dissertação (Mestrado em Artes Visuais) - Escola de Comunicações e Artes (ECA), Universidade de São Paulo, [2008].

GRIFFITHS, Glyn; GRIFFITHS, Cynthia. Aspectos da Língua Kadiwéu. Brasília: Summer Institute of Linguistics, 1976. (Série Lingüística, 6).

GUSS, David. To wave and sing: art, symbol and narrative in the south American Rain Forest. Los Angeles: University of California Press, 1990.

KOLLER LECZNIESKI, Lisiane. Estranhos laços: predação e cuidado entre os Kadiwéu. 2005, 325 f. Tese (Doutorado em Antropologia Social) - PPGAS/UFSC, [2005].

LAGROU, Els. O que nos diz a arte kaxinawa sobre a relação entre identidade e alteridade? Revista Mana, Rio de Janeiro, v. 8, n. 1, p. 29-61, 2002.

No caminho das miçangas: arte, alteridade e relação entre os ameríndios. In: Simpósio Arte Imagem Memória. Rio de Janeiro: Museu Nacional/UFRJ, 2007a. s./p.

A fluidez da forma: arte, alteridade e agência em uma sociedade amazônica (Kaxinawa, Acre). Rio de Janeiro: TopBooks, 2007b.

LÉVI-STRAUSS, Claude. Indian cosmetics. V.V.V., New York, v. 1, p. 33-35, jun. 1942.

O desdobramento da representação nas artes da Ásia e da América. In:

Antropologia Estrutural. Rio de Janeiro: Tempo Brasileiro, 1996. p. 288-294.

Tristes Trópicos. São Paulo: Companhia das Letras, 2001.

LOPES DA SILVA, Aracy; FARIAS, Agenor. Pintura corporal e sociedade: os 'partidos' xerente. In: VIDAL, Lux (Org.). Grafismo Indígena. São Paulo: Nobel/Fapesp/Edusp, 1992. p. 89-116.

MACEDO, Silvia L. S. O belo expressivo: a comunicabilidade dos padrões gráficos ameríndios. Espaço Ameríndio, Porto Alegre, v. 1, n. 1, p. 62-72, jun./dez. 2007.

MÜLLER, Regina Pollo. Tayngava: a noção de representação na arte gráfica. In: VIDAL, Lux (Org). Grafismo Indígena. São Paulo: Nobel/Fapesp/Edusp, 1992. p. 231-248.

Os assuriní do Xingu: história e arte. Campinas: Unicamp, 1993.

NOVAES, Sylvia C. Jogos de espelho. São Paulo: Edusp, 1993.

PECHINCHA, Mônica. Histórias de admirar: mito, rito e história Kadiwéu. 1994. 210

f. Dissertação (Mestrado em Antropologia Social) - UnB, [1994]. 
LISIANE KOLLER LECZNIESKI - Objetos relacionais ameríndios...

RIBEIRO, Darcy. Kadiwéu: Ensaios etnológicos sobre o saber, o azar e a beleza. Petrópolis: Vozes, 1980.

RODRIGUES DO PRADO, Francisco. História dos índios cavalleiros ou da nação Guaycurú. Revista do Instituto Histórico e Geográfico Brasileiro, Rio de Janeiro, v. 1, p. 25-57, 1839.

SÁNCHEZ-LABRADOR, José. Eı Paraguay Católico (I e II). Buenos Aires: Imprenta de Coni Hermanos, 1910.

SANDALO, Filomena. Gender and social class in Kadiwéu phonology. In: Proceedings of the 4th Berkeley Women and Language Conference: Gender and Belief Systems. Berkeley: 4th Berkeley Women and Language Conference, 1996. p. 645-658.

SIQUEIRA JÚNIOR, Jaime G. Arte e técnicas Kadiwéu. São Paulo: Secretaria Municipal de Cultura, 1992.

. Esta terra custou o sangue de nossos avós: a construção do tempo e espaço Kadiweu. 1993. 290 f. Tese (Mestrado em Antropologia Social) - USP, [1993].

SUSNIK, Branislava. Los aborígenes del Paraguay V: ciclo vital e estrutura social. Asunción: Museo Etnografico Andres Barbero, 1983.

Etno-historia de Paraguai. América Indígena, Cidade do México, v. 49, n. 3, p. 431-490, 1989.

VAN VELTHEM, Lucia. O belo é a fera: a estética da produção e da predação entre os Wayana. Lisboa: Assírio \& Alvim, 2003.

VIDAL, Lux. Pintura corporal e arte gráfica entre os Kaiapó-Xicrin do Catete. In: (Org.). Grafismo indígena: estudos de antropologia estética. São Paulo: Studio Nobel/Fapesp/Edusp, 1992. p. 143-189.

VILAÇA, Aparecida. Comendo como gente: formas do canibalismo wari'. Rio de Janeiro: Editora da UFRJ, 1992.

VIVEIROS DE CASTRO, Eduardo. Os pronomes cosmológicos e o perspectivismo ameríndio. Mana, Rio de Janeiro, v. 2, n. 2, p. 115-144, 1996.

The forest of mirrors: a few notes on the ontology of Amazonian spirits. 2004. Disponível em: http://amazone.wikia.com/wiki/The Forest of Mirrors . Acesso em: 10 jun. 2010.

Espaço Ameríndio, Porto Alegre, v. 4, n. 1, p. 61-91, jan./jun. 2010. 